\title{
PELAKSANAAN PENDIDIKAN DAN PELATIHAN TERHADAP KINERJA GURU MADRASAH DI KOTA GORONTALO
}

\section{THE TRAINING AND EDUCATION IMPLEMENTATION ON MADRASA TEACHER'S PERFORMANCE IN GORONTALO}

\section{Mujizatullah', Mustolehudin²}

${ }^{1}$ Balai Penelitian dan Pengembangan Agama Makassar, Kementerian Agama, Jl. A.P. Pettarani No. 72, Makassar

${ }^{2}$ Balai Penelitian dan Pengembangan Agama Semarang Kementerian Agama, Jl. Untung Suropati Kav 70

Bambankerep, Ngaliyan Semarang

E-mail: mujizatullah@kemenag.go.id

Naskah Diterima: 30 Juli 2019; Direvisi: 14 November 2019; Disetujui: 24 November 2019

\begin{abstract}
This study aimed to find out the influence level of subject teachers' training and education for the improvement of madrasah teacher's performance in Gorontalo. This study used a survey and quantitative research method. The result of this research showed that training and education implementation had influenced the madrasa teacher's performance in Gorontalo. There was an increase in madrasa teacher\&\#39; four competencies after they joined the training, which are pedagogical competence, personality competence, professional competence, and social competence. Respondents said that the trainers (widyaiswara) could explain the material substance well (score 4.4). The trainers have much understood and competent in the training aims and procedures. So, the academic qualification of the trainers is appropriating with their primary tasks by involving qualified and professional instructors. Nevertheless, some trainers were not mastering in presenting training material. Furthermore, the training materials are considering inadequate for the training participants.
\end{abstract}

Keywords: Education; Gorontalo; Influence; Madrasa teacher; Training

\begin{abstract}
Abstrak
Penelitian ini bertujuan untuk mengetahui tingkat pengaruh pendidikan dan pelatihan mata pelajaran terhadap peningkatan kinerja guru madrasah di Kota Gorontalo. Metode yang digunakan dalam penelitian ini adalah survei dan metode kuantitatif. Hasil penelitian menunjukkan bahwa pelaksanaan pendidikan dan pelatihan terhadap guru madrasah di Kota Gorontalo, memiliki pengaruh terhadap kinerja guru. Pengaruh tersebut adalah guru memiliki peningkatan dalam kompetensi pedagogik, kompetensi kepribadian, kompetensi profesional, dan kompetensi sosial setelah mengikuti kediklatan. Responden menjelaskan bahwa widyaiswara mampu menyampaikan materi dengan baik dengan skor 4,4. Widyaiswara cukup memahami dan menguasai tujuan dan prosedur penyelenggaraan diklat sehingga kualifikasi akademik widyaiswara sesuai dengan tugas pokoknya dengan melibatkan instruktur yang kompeten dan profesional. Namun demikian, masih terdapat beberapa Widyaiswara dalam pelaksanaan diklat dianggap masih kurang memadai dalam membawakan materi. Selain itu, ketersediaan bahan ajar bagi peserta diklat dianggap masih kurang memadai.
\end{abstract}

Kata Kunci: Pengaruh; Pendidikan; Pelatihan; Guru madrasah; Gorontalo 


\section{PENDAHULUAN}

Tenaga pendidik dituntut untuk selalu meningkatkan pengetahuan dan kemampuan dalam menunjang profesinya. Menurut Sudjana (1989: 192), pendidik harus peka terhadap perubahan yang terjadi dalam bidang pendidikan dan pengajaran. Guru yang profesional adalah guru yang dapat melakukan tugas KBM dengan baik. Dalam mengajar diperlukan keterampilan-keterampilan yang dibutuhkan untuk kelancaran proses belajar mengajar secara efektif dan efisien. Menurut Saud setidaknya ada 10 keterampilan yang harus dimiliki oleh seorang guru dalam proses belajar mengajar. Kesepuluh syarat tersebut antara lain keterampilan membuka pelajaran, keterampilan menjelaskan, keterampilan bertanya, keterampilan memberikan penguatan, keterampilan memberi motivasi, keterampilan menggunakan media pembelajaran, keterampilan membimbing diskusi kelompok kecil, keterampilan mengadakan variasi, keterampilan mengajar perorangan dan kelompok kecil, dan keterampilan menutup pelajaran (Saud, 2008: 59). Beberapa keterampilan tenaga pendidik tersebut, dapat memberikan penguatan sebagai salah satu kompetensi pedagogik. Penguatan verbal ialah ucapan yang singkat tetapi mempunyai pengaruh yang besar. Pengaruh tersebut dapat mendorong atau memacu ke pendidikan yang lebih baik, tetapi dapat pula menghentikan suatu aktivitas siswa baik lahiriah maupun batiniah (Sadirman, 2004: 208).

Tenaga pendidik merupakan prasyarat utama yang harus dipenuhi terlebih dahulu bagi berlangsungnya proses belajar mengajar. Hal ini diperlukan untuk menjamin optimalisasi hasil pembelajaran secara kurikuler, yakni tersedianya guru dengan kualifikasi dan kompetensi yang mampu memenuhi tuntutan tugasnya. Suparlan menjelaskan bahwa seorang pendidik setidaknya harus memiliki kemampuan 5M, yaitu merencanakan pembelajaran; melaksanakan pembelajaran tatap muka; menilai/memberikan nilai/skor hasil belajar siswa; melaksanakan bimbingan; dan tugas tambahan seperti pembinaan pramuka ataupun wali kelas. Tenaga pendidik sebagai ujung tombak pelaksanaan pendidikan, mestinya diberdayakan, diberi berbagai pelatihan, retraining, reedukasi, dan semacamnya (Suparlan, 2011: 3).

Regulasi yang mengatur tentang peningkatan mutu pendidik, di atur dalam Undang-Undang Nomor 20 Tahun 2003 tentang Sistem Pendidikan Nasional, Bab I Ketentuan Umum, bahwa tenaga pendidik adalah tenaga kependidikan yang berkualifikasi sebagai guru, dosen, konselor, pamong belajar, widyaiswara, tutor, instruktur, fasilitator dan sebutan lain yang sesuai dengan kekhususannya, serta berpartisipasi dalam proses penyelenggaraan pendidikan.

Kegiatan pelatihan bagi guru pada
dasarnya merupakan upaya untuk
mengembangkan pengetahuan dan
keterampilan guru sehingga pada gilirannya diharapkan para guru dapat memperoleh keunggulan kompetitif dan dapat memberikan pelayanan yang sebaik-baiknya. Dengan kata lain, mereka dapat bekerja secara lebih produktif dan mampu meningkatkan kualitas kinerjanya di antaranya LPTK yang secara otoritatif menjadi wadah lahirnya guru yang diharapkan berkualitas dan memiliki kapasitas (Cowling, Alan \& James 1996: 110).

Selain hal tersebut di atas, Lembaga Pendidikan dan Pelatihan (Diklat) yang "didaulat" untuk melakukan pendidikan serta pelatihan secara terencana, terukur dan berkesinambungan terhadap guru, tak terkecuali guru-guru yang mengabdi di Madrasah. Sebagaimana ditekankan dalam Rencana Strategis (Renstra) Badan Litbang dan Diklat Kementerian Agama Tahun 2014-2019, yakni meningkatkan kualitas diklat tenaga teknis pendidikan dan keagamaan, melalui (1) Peningkatan SDM penyelenggaraan diklat; (2) Peningkatan kualifikasi akademik dan kepakaran di kalangan widyaiswara; (3) Peningkatan kualitas sistem penyelenggaraan diklat; (4) Diversifikasi penyelenggaraan diklat melalui Diklat di Tempat Kerja (DDTK) dan Diklat Jarak Jauh (DJJ); (5) Pemanfaatan hasil penelitian untuk kepentingan diklat; dan (6) Peningkatan kualitas sistem penjaminan mutu diklat.

Pendidikan dan pelatihan untuk guru di bawah Kementerian Agama sudah dilakukan oleh Pusdiklat Badan Litbang dan Diklat juga oleh Balai Diklat Keagamaan (BDK) RI, akan 
tetapi belum semua guru memperoleh kesempatan untuk mengikut pendidikan dan pelatihan. Belum meratanya akses pendidikan dan pelatihan bagi guru madrasah, dapat menjadi salah satu indikator kurang profesionalisme guru dalam KBM. Penelitian ini ditujukan untuk mengevaluasi proses penyelenggaraan diklat selama ini, menjadi signifikan untuk dilakukan, terutama dalam rangka mengukur dan mendeskripsikan pengaruh program diklat tersebut terhadap performa atau kinerja guru Madrasah Ibtidaiyyah, Madrasah Tsanawiyah, dan guru Madrasah Aliyah. Berikut ini adalah kondisi guru madrasah di Kota Gorontalo yang pernah mengikuti pendidikan dan pelatihan.

Tabel 1. Kondisi guru MI tahun 2009 sampai 2018

\begin{tabular}{|c|c|c|c|c|c|c|c|c|c|c|c|}
\hline \multirow{2}{*}{ Sekolah } & \multirow{2}{*}{$\begin{array}{l}\text { Jumlah guru } \\
\text { (orang) }\end{array}$} & \multicolumn{10}{|c|}{ Diklat tahun } \\
\hline & & 2009 & 2010 & 2011 & 2012 & 2013 & 2014 & 2015 & 2016 & 2017 & 2018 \\
\hline MIS Muh Kota Utara & 7 & & & 3 & & & 1 & & 3 & & \\
\hline MIS Al Wathaniyah & 4 & & & & 1 & & & 1 & & & 2 \\
\hline MIS Al Yusra & 7 & & 1 & 1 & 2 & 1 & & & & & 2 \\
\hline MIS Darul Mubien & 7 & 2 & & 4 & 1 & & & & & & \\
\hline MIS Muh Unggulan & 10 & & & 1 & & & & & 6 & 2 & 1 \\
\hline MIS Al Khairat & 6 & 2 & & 1 & & & & & 1 & & 2 \\
\hline MIN 1 Gorontalo & 4 & & & & & & & & & 4 & \\
\hline Total & & 4 & 1 & 10 & 4 & 1 & 1 & 1 & 10 & 6 & 7 \\
\hline
\end{tabular}

Tabel 2. Kondisi guru MTs tahun 2009 sampai 2018

\begin{tabular}{|c|c|c|c|c|c|c|c|c|c|c|c|}
\hline \multirow{2}{*}{ Sekolah } & \multirow{2}{*}{$\begin{array}{l}\text { Jumlah guru } \\
\text { (orang) }\end{array}$} & \multicolumn{10}{|c|}{ Diklat tahun } \\
\hline & & 2009 & 2010 & 2011 & 2012 & 2009 & 2014 & 2015 & 2016 & 2009 & 2018 \\
\hline MTs N 1 Gorontalo & 41 & 5 & 4 & 3 & 3 & & & & 1 & 1 & 8 \\
\hline MTs Nurul Yaqin & 6 & & & & & & & 1 & 3 & 1 & 1 \\
\hline MTs Darul Mubien & 8 & & & 1 & & & & & 2 & 3 & 2 \\
\hline MTs Al Yusra & 7 & & 1 & & & & & & 4 & 1 & 1 \\
\hline MTs Al Khairat & 1 & & & 1 & & & & & 2 & & \\
\hline MTs Al Huda & 12 & & & & 1 & 1 & & & 2 & 5 & 3 \\
\hline MTs Muhammadiyah & 4 & & & & 1 & & & & & 2 & 1 \\
\hline Total & & 5 & 5 & 5 & 5 & 1 & & 1 & 14 & 13 & 16 \\
\hline
\end{tabular}

Tabel 3. Kondisi guru MA

\begin{tabular}{|c|c|c|c|c|c|c|c|c|c|c|c|}
\hline \multirow{2}{*}{ Sekolah } & \multirow{2}{*}{$\begin{array}{l}\text { Jumlah guru } \\
\text { (orang) }\end{array}$} & \multicolumn{10}{|c|}{ Diklat tahun } \\
\hline & & 2009 & 2010 & 2011 & 2012 & 2013 & 2014 & 2015 & 2016 & 2017 & 2018 \\
\hline MAS Muhammadiyah & 9 & & & & & 1 & 1 & & 1 & 1 & 5 \\
\hline MAS Nurul Yaqin & 1 & & & & & & & & & 1 & \\
\hline MAS Al Yusra & 5 & 1 & 1 & 1 & & 1 & & & 1 & & \\
\hline MAS Al Huda & 7 & & & 1 & 2 & & & & 2 & & 1 \\
\hline MAN 1 Pohu Wato & 4 & & & & 1 & 1 & & & & 2 & \\
\hline MAN Al Falah & 6 & & & 2 & & 1 & & & & 1 & \\
\hline MAN Al Hikmah & 1 & & & & & & 1 & & & & \\
\hline MAN 1 Gorontalo & 15 & 1 & 3 & 3 & 2 & & & & & 1 & 2 \\
\hline Total & & 2 & 4 & 7 & 5 & 4 & 2 & & 4 & 6 & 8 \\
\hline
\end{tabular}

Berdasarkan latar belakang tersebut, rumusan masalah dalam penelitian ini adalah bagaimana performa diklat keagamaan dan sejauh mana pengaruh diklat mata pelajaran terhadap peningkatan kinerja guru mata pelajaran di madrasah di Kota Gorontalo?. Penelitian ini bertujuan untuk mengukur dan mendeskripsikan performa penyelenggaraan diklat guru yang selama dua tahun terakhir, yang berjalan di beberapa diklat keagamaan, serta pengaruh penyelenggaraan pendidikan dan pelatihan guru mata pelajaran tersebut terhadap capaian kinerja mereka di madrasah yang ada di Kota Gorontalo, dilihat dari sisi konteks, input, proses dan produk (outcome), termasuk layanan yang sejatinya menjadi kewajiban balai-balai 
diklat tersebut, meliputi: materi diklat, metode diklat, dan ketersediaan pelatih (trainer) yang kompeten.

\section{Kajian Literatur}

Membahas pendidikan dan pelatihan bagi guru madrasah merupakan hal sangat strategis dalam rangka meningkatkan mutu pendidikan agama di madrasah. Sejatinya regulasi yang mengatur tentang pendidikan dan pelatihan guru telah diatur dengan jelas, akan tetapi dalam implementasinya belum semua guru madrasah dapat mengaksesnya. Hal ini sebagaimana dijelaskan dalam Peraturan Menteri Agama Nomor 43 tahun 2016 tentang Sistem Informasi Manajemen Pendidikan dan Pelatihan pada Kementerian Agama, Pasal 1, ayat (2), "Pendidikan dan Pelatihan yang selanjutnya disebut Diklat adalah penyelenggaraan pembelajaran dan pelatihan dalam rangka mengembangkan kompetensi pegawai sesuai persyaratan jabatan masingmasing pada Kementerian Agama".

Salah satu UPT yang menyelenggarakan pendidikan dan pelatihan bagi guru madrasah adalah BDK. Tugas BDK adalah melakukan kegiatan Pendidikan dan pelatihan sebagaimana tercantum dalam Pasal 1 Ayat (11) Peraturan Menteri Agama Nomor 4 tahun 2013 bahwa, BDK adalah unit pelaksana Teknis di lingkungan Badan Penelitian dan Pengembangan serta Pendidikan dan Pelatihan Kementerian Agama, Pasal 2 bahwa, tujuan dilakukannya Pendidikan dan Pelatihan oleh Balai Diklat adalah untuk meningkatkan kompetensi teknis PNS dan Pegawai non-PNS yang meliputi pengetahuan, keahlian, keterampilan, sikap dan perilaku agar sesuai dengan standar kompetensi teknis yang dibutuhkan oleh satuan organisasi dan/atau jabatannya. Konsekuensi logis dari tugas pokok dan fungsi BDK adalah melayani dan melakukan pengelolaan kegiatan diklat sehingga tercapainya tujuan dan dalam pelaksanaannya sejatinya tetap mengacu pada standar kediklatan meliputi isi, proses, kompetensi alumni, tenaga kediklatan, sarana prasarana, pengelolaan, pembiayaan, dan evaluasi (Puspayanti 2016: 29).

Mengacu UU Nomor 14 Tahun 2005 tentang guru dan dosen, dijelaskan bahwa kinerja guru adalah jumlah keluaran (output dan outcome) dari indikator-indikator pelaksanaan profesi tersebut. Guru sebagai pengampu profesi tertentu merupakan bidang pekerjaan khusus yang dalam pelaksanaannya memiliki kemampuan, yaitu 1) memiliki bakat, minat, panggilan jiwa, dan idealisme; 2) memiliki komitmen untuk meningkatkan mutu Pendidikan, keimanan, ketakwaan, dan akhlak mulia; 3) memiliki kualifikasi akademik dan latar belakang Pendidikan sesuai dengan bidang tugas; 4) memiliki kompetensi yang diperlukan sesuai dengan bidang tugas; dan 5) memiliki tanggung jawab atas pelaksanaan tugas keprofesionalan.

Penelitian tentang pendidikan dan pelatihan bagi guru madrasah sejatinya sudah dilakukan oleh peneliti terdahulu, akan tetapi penelitian yang meneliti tentang Pengaruh Pendidikan dan Pelatihan Terhadap Kinerja Guru Madrasah di Kota Gorontalo sepanjang penelusuran penulis belum banyak dilakukan. Berikut ini adalah beberapa kajian yang cukup relevan dan bersinggungan dengan penelitian ini.

Kajian yang dilakukan Athiyah (2019) tentang evaluasi kediklatan, lebih menitikberatkan pada aspek penerapan model CIPP pada Implementasi program Diklat Teknis Substantif Ujian Nasional (UN) Bahasa Inggris Madrasah Aliyah Pusdiklat Tenaga Teknis Pendidikan dan Keagamaan pada tahun 2018 didapat kesimpulan bahwa pelaksanaannya telah berjalan dengan baik (sistematik, terencana, teratur, dan berkesinambungan). Penelitian lain yang cukup bersinggungan adalah kajian yang dilakukan Wibowo (2013: 245) mengenai kinerja guru madrasah pasca diklat diperoleh temuan sebagai berikut: Kinerja guru agama Madrasah Aliyah pasca mengikuti diklat fungsional dilihat dari kompetensi pedagogis, kepribadian, sosial, profesional termasuk dalam kategori cukup. Namun dalam hal prestasi, guru agama Madrasah Aliyah kurang memiliki prestasi yang menonjol. (2) Kinerja guru agama Madrasah Aliyah setelah mengikuti diklat fungsional berdampak baik terhadap prestasi belajar siswa. (3) Iklim akademis sekolah berupa sarana pendukung, manajemen, program dan regulasi serta komitmen kepala madrasah berdampak 
baik pada kinerja guru agama pasca diklat sedangkan fasilitas yang tersedia di madrasah tidak ikut mendukung dalam peningkatan kinerja guru agama. (4) Kinerja guru agama setelah mengikuti diklat berdampak positif terhadap kinerja guru yang lain.

Kajian lain yang relevan dengan penelitian ini adalah penelitian yang dilakukan Djailani terhadap kompetensi guru pada MTs N Kota Banda Aceh. Fokus kajian Djailani (2012) lebih menekankan pada aspek pengembangan dan peningkatan kompetensi guru harus dilakukan secara sistemik, sistematis, berorientasi pada empat kompetensi guru. Adapun penelitian ini lebih memfokuskan pada aspek guru madrasah pasca mengikut diklat. Hal ini berbeda dengan temuan penelitian Wibowo (2015) terhadap Problematika Profesi Guru Dan Solusinya Bagi Peningkatan Kualitas Pendidikan Di MTs. Negeri Nguntoronadi Kabupaten Wonogiri. Menurut Wibowo bahwa problem yang terjadi pada guru karena beberapa faktor kompetensi, yaitu (a) kompetensi pedagogis, yaitu lemahnya menguasai kelas, miskin inovasi dan kreativitas, minat baca rendah, kurang menguasai teknik penilaian yang baik dan guru kurang bahkan tidak menguasai media pembelajaran yang berbasis teknologi informasi, (b) kompetensi profesional, yaitu kurang menguasai materi, (c) kompetensi kepribadian, yaitu sikap kurang mencintai pada profesi.

Sementara itu penelitian yang dilakukan Nuranti, Hanief \& Mustafida (2019) tentang Strategi Guru dalam Membentuk Karakter Siswa di Madrasah Ibtidaiyah Bustanul Ulum Kota Batu diperoleh temuan bahwa karakter yang tampak dalam diri siswa di Madrasah Ibtidaiyah Bustanul Ulum Kota Batu telah mengarah pada pedoman pelaksanaan pendidikan karakter dari Kementerian Pendidikan dan Kebudayaan. Karakter siswa terbentuk salah satunya melalui strategi guru dalam menerapkan pembelajaran di kelas. Penelitian lain yang senada tentang peningkatan kualitas guru adalah yang dilakukan Faizah, Hanief \& Dina (2019) dengan tema Profesionalisme Guru Dalam Meningkatkan Mutu Pendidikan Di Msadrasah Ibtidaiyah Tahfidz Al-Asyhar Malang. Temuan penelitiannya menunjukkan bahwa; guru yang profesional memiliki 4 kemampuan, yaitu kompetensi pedagogik, kompetensi kepribadian, dan kompetensi sosial. Peningkatan pendidikan dapat ditempuh melalui: 1) Standar Sarana Prasarana, 2) Standar pendidik dan tenaga kependidikan 3) Standar Isi 4) Standar Proses. 5) Standar Pengelolaan, yaitu pengelolaan 8 Standar Nasional Pendidikan.

Penelitian yang dilakukan Nurhilaliati (2019) lebih difokuskan pada upaya menilai kualitas dan memprediksi prospek kepemimpinan kepala madrasah perempuan di pondok pesantren di Kabupaten Lombok Barat. Kajian ini menemukan bahwa Kepemimpinan kepala madrasah perempuan di pondok pesantren dapat dikategorikan memiliki kualitas yang cukup baik. Berdasarkan sembilan indikator yang digunakan, terdapat tujuh indikator yang muncul pada semua subjek penelitian, yaitu kedewasaan emosional, objektif, perseptif, adaptasi, inisiatif, kreativitas, dan skill berkomunikasi. Indikator tanggung jawab tidak muncul secara maksimal pada satu subjek penelitian. Demikian juga indikator percaya diri. Perempuan memiliki prospek yang baik untuk berada di posisi pimpinan karena adanya kualitas. Tidak ada penolakan signifikan terhadap pemimpin perempuan, dan tidak ada pembedaan kesempatan bagi perempuan dan laki-laki untuk menjadi pemimpin, selama memiliki kemampuan.

Kajian-kajian lain yang cukup relevan dengan penelitian ini seperti yang dilakukan Sumarni (2017); Sopandi (2019); Miyono \& Rosidin (2017); Hanun (2018); dan penelitian Hidayati (2018) memiliki fokus kajian yang berbeda-beda. Penelitian Sumarni lebih menekankan pada aspek kurikulum 2013 di madrasah. Sedangkan penelitian Sopandi menekankan evaluasi pendidikan di Madrasah Aliyah, kajian Miyono dan Rosidin menekankan pada aspek kompetensi dan motivasi kerja guru di madrasah, hasil penelitian Hanum menitikberatkan aspek evaluasi kediklatan, dan artikel Hidayati temuan penelitiannya terkait dengan pelaksanaan sekolah lima hari kerja di madrasah. Berdasarkan penelusuran literatur tersebut di atas, penelitian ini kiranya penting dilakukan 
untuk melihat performa dan pengaruh pendidikan dan pelatihan terhadap guru madrasah di Kota Gorontalo.

Variabel dalam penelitian ini dikelompokkan menjadi variabel bebas dan variabel terikat. Variabel bebas adalah pendidikan dan pelatihan yang terdiri dari metode yang digunakan $\left(\mathrm{X}_{1}\right)$, materi pendidikan dan latihan $\left(\mathrm{X}_{2}\right)$ dan pelatih diklat $\left(\mathrm{X}_{3}\right)$. Sedangkan variabel terikat adalah kinerja guru (Y). Pengukuran variabel yang digunakan dalam penelitian ini adalah dengan menggunakan Skala Likert, mengukur dengan cara menghadapkan seorang responden pada sebuah pertanyaan dan kemudian diminta untuk memberikan jawaban yang diberi skor 1 sampai 5, yaitu Sangat Baik: skor 5, Baik: skor 4, Tidak Tahu: skor 3, Kurang Baik: skor 2, Sangat tidak Baik: skor 1.

Analisis regresi digunakan menganalisis pengaruh variabel bebas terhadap variabel terikat. Model yang dipergunakan adalah regresi linier berganda (multiple linier regression) analisis regresi yang lazim digunakan untuk menganalisis data yang terdiri atas sejumlah peubah $\mathrm{X}$ dengan sebuah peubah Y dengan formula menurut Walpole dan Myers dalam (Furqon 2009: 231) sebagai berikut:

$$
\mathrm{Y}=\mathrm{a}+\mathrm{b}_{1} \mathrm{X}_{1}+\mathrm{b}_{2} \mathrm{X}_{2}+\mathrm{b}_{3} \mathrm{X}_{3}+\mathrm{e}
$$

Dimana: $\mathrm{Y}=$ Kinerja guru, $\mathrm{a}=$ Konstanta, $\mathrm{b}-=$ Koefisien regresi, $\mathrm{X}_{1}=$ Metode yang digunakan, $\mathrm{X}_{2}=$ Materi pendidikan dan latihan, $\mathrm{X}_{3}=$ Pelatih/instruktur pendidikan dan latihan, $\mathrm{e}=$ variabel eror.

Multikolinieritas berarti adanya hubungan linier yang sangat kuatantar variabel bebas dalam regresi. Model regresi yang bagus mengasumsikan tidak adanya multikolinieritas atau tidak adanya hubungan yang sempurna antar variabel bebas yang satu dengan lainnya. Heteroskedastisitas berarti variasi residual tidak sama untuk semua pengamatan, atau semakin besarnya residual untuk pengamatan yang semakin banyak. Model regresi yang baik adalah residual bersifat konstan atau sama untuk berbagai pengamatan.

Uji normalitas bertujuan untuk menguji apakah dalam model regresi kedua variabel (bebas dan terikat) mempunyai distribusi normal atau tidak. Model regresi yang baik adalah model yang memiliki distribusi data normal atau mendekati normal. Selanjutnya hasil analisis regresi linier berganda diuji dengan pengujian secara simultan maupun parsial, sehingga hasil temuannya memenuhi standar signifikansi yang baku. Pengujian secara bersama-sama (simultan) dilakukan untuk mengetahui berapa pengaruh dari variabel bebas $\left(\mathrm{X}_{1}, \mathrm{X}_{2}\right.$ dan $\left.\mathrm{X}_{3}\right)$ secara bersamaan terhadap variabel terikat (Y). Untuk itu digunakan teknik "Uji F" dengan formula menurut (Sudjana, 1989) sebagai berikut:

$$
\mathrm{F}=\frac{\mathrm{JKreg} / \mathrm{k}}{\mathrm{JK} \text { res } /(\mathrm{n}-\mathrm{k}-1)}
$$

Dimana: JKreg= Jumlah kuadrat regresi, JKres $=$ Jumlah kuadrat residu, $\mathrm{K}=$ Banyaknya variabel bebas, $\mathrm{n}=$ Banyak subyek.

Apabila nilai signifikansi $\mathrm{F}$ lebih kecil dari $5 \%(0,05)$ atau $\mathrm{F}$ hitung $>\mathrm{F}$ tabel, maka dinyatakan signifikan yang berarti secara bersama-sama variabel bebas berpengaruh terhadap variabel terikat. Dan sebaliknya, bila signifikasi $\mathrm{F}$ lebih besar dari 5\% $(0,05)$ atau $\mathrm{F}$ hitung $<\mathrm{F}$ tabel, berarti secara bersama-sama variabel bebas tidak berpengaruh tidak variabel terikat. Selanjutnya ketepatan model regresi ditunjukkan dengan melihat angka koefisien determinasi $\left(\mathrm{R}_{2}\right)$ yang menunjukkan kemampuan variabel bebas dalam menjelaskan perubahan variabel terikat. Semakin besar nilai $\mathrm{R}_{2}$ (mendekati satu) maka peranan variasi variabel bebas terhadap variabel terikat semakin besar dan sebaliknya.

Pengujian secara parsial dilakukan untuk mengetahui pengaruh masing-masing variabel bebas yaitu $\left(\mathrm{X}_{1}\right),\left(\mathrm{X}_{2}\right)$, dan $\left(\mathrm{X}_{3}\right)$ terhadap variabel terikat (Y). Untuk itu digunakan teknik "Uji t" dengan formula sebagai berikut:

$$
\mathrm{t}=\frac{\mathrm{bi}}{\mathrm{Sbi}}
$$

Dimana: bi= Koefisien regresi, $\mathrm{Sbi}=$ Standar error koefisien regresi.

Apabila nilai signifikansi t lebih kecil dari 5\% atau t hitung $>\mathrm{t}$ tabel, maka dinyatakan signifikan yang berarti secara parsial variabel bebas berpengaruh terhadap variabel terikat. Dan sebaliknya bila signifikansi tlebih besar dari $5 \%(0,05)$ atau $t$ hitung $>\mathrm{t}$ tabel, maka 
secara parsial variabel bebas tidak berpengaruh terhadap variabel terikat. Pengujian hipotesis ini digunakan untuk menguji variabel-variabel bebas yang mempunyai pengaruh paling dominan terhadap variabel terikat.

Hipotesis statistik dinyatakan sebagai berikut: Ho: $\beta 1=\beta 2=\beta 3=0$, Hipotesis null $(\mathrm{Ho})$ ini berarti bahwa variabel bebas tidak berpengaruh dominan terhadap variabel terikat. Ha: Minimal salah satu koefisien \# 0, Hipotesis alternatif $(\mathrm{Ha})$ ini berarti bahwa salah satu variabel bebas berpengaruh dominan terhadap variabel terikat. Apabila di antara variabelvariabel bebas yang mempunyai nilai koefisien regresi (R) lebih besar di antara yang lainnya. Maka, variabel tersebut merupakan variabel yang paling dominan berpengaruh terhadap variabel terikat.

\section{METODE PENELITIAN}

Metode yang digunakan dalam penelitian ini adalah menggunakan survei dan metode kuantitatif. Teknik analisis korelasi product moment, dalam upaya melihat pengaruh variabel bebas atau variabel $\mathrm{X}$ (pendidikan dan pelatihan) terhadap variabel terikat (kinerja guru). Penelitian ini merupakan penelitian penjelasan (explanatory research) dengan menggunakan metode survai yaitu penelitian yang berusaha menjelaskan hubungan kausal antara variabel-variabel melalui pengujian hipotesis. Uji hipotesis dapat menjelaskan pengaruh antara variabel bebas dan variabel terikat, sekaligus deteksi pengaruh yang paling kuat antara variabel bebas tersebut.

Populasi dalam penelitian ini, sebagaimana lazim digunakan dalam penelitian kuantitatif dengan teknik survei, yang dimaknai (Morissan, 2014: 165) sebagai penelitian yang memilih sejumlah responden sebagai sampel, dan memberikan kuesioner yang standar (baku), di mana para pengambil kebijakan menggunakan hasil survei sebagai acuan pertimbangan. Dalam konteks penelitian ini populasi dan sampelnya terdiri dari Guru Madrasah Ibtidaiyyah, Tsanawiyah, dan Aliyah yang telah mengikuti Diklat Mata Pelajaran tahun 2016-2017 pada Wilayah Kerja BDK Manado, dan Ambon. Teknik pengambilan sampel menggunakan metode Proportional Random Sampling, jumlah sampel yang diambil dari populasi, ditentukan dengan menggunakan rumus Slovin (Sevilla, 1993: 161) sebagai berikut:

$n=\frac{N}{1+N(e)^{2}}$

Dimana: $\mathrm{N}=$ jumlah/jumlah populasi, $\mathrm{n}=$ ukuran/jumlah sampel, e= nilai kritis (batas ketelitian) yang dinginkan (persen kelonggaran ketidaktelitian karena kesalahan pengambilan sampel populasi yaitu, sebesar 0,01 .

Berdasarkan pertimbangan waktu dan keterbatasan dana, maka kegiatan peneliti di BDK Manado mendistribusikan angket sebanyak 24 dan di Provinsi Maluku Utara sebanyak 22 angket pada lokasi penelitian masing-masing, dengan memilih guru secara purposif (sengaja) dengan tetap memastikan bahwa, guru/responden tersebut merupakan alumni diklat mata pelajaran tahun 2016-2017.

Data-data yang dibutuhkan dalam penelitian ini menggunakan instrumen kuesioner digunakan untuk menjaring data kuantitatif yang dikembangkan dimulai dengan telaah literatur mengenai variabel yang diteliti yang dikembangkan lebih jauh menjadi beberapa indikator.

Teknik analisis data akan menggunakan analisis statistik inferensial yang berfungsi untuk menggeneralisasikan hasil penelitian ini dengan beberapa sampel terhadap populasi penelitian (seluruh guru madrasah yang mengikuti diklat tahun 2016-2017). Teknik korelasi product moment, digunakan dalam upaya melihat pengaruh variabel bebas atau variabel $X$ (pendidikan dan pelatihan) terhadap variabel terikat (kinerja guru). Sebagaimana dikemukakan sebelumnya, bahwa, penelitian ini merupakan penelitian kebijakan dengan menggunakan metode survei yaitu penelitian yang berusaha menjelaskan hubungan kausal antara variabel-variabel melalui pengujian hipotesis. Uji hipotesis dapat menjelaskan pengaruh antara variabel bebas dan variabel terikat, sekaligus deteksi pengaruh yang paling kuat antara variabel bebas tersebut. Hasil analisis dan interpretasi tadi, akan disajikan menggunakan grafik distribusi frekuensi dan korelasi regresi berganda terkait dengan datadata kuantitatif, dan dideskripsikan secara naratif berkenaan dengan data-data kualitatif. 


\section{HASIL DAN PEMBAHASAN}

\section{Setting Sosial Keagamaan Masyarakat Gorontalo}

Gorontalo dikenal sebagai salah kota perdagangan, pendidikan, dan pusat pengembangan kebudayaan Islam di Indonesia Timur. Sejak dulu Gorontalo dikenal sebagai Kota Serambi Madinah. Hal itu disebabkan pada waktu dahulu Pemerintahan Kerajaan Gorontalo telah menerapkan syariat Islam sebagai dasar pelaksanaan hukum, baik dalam bidang pemerintahan, kemasyarakatan, maupun pengadilan. Hal ini dapat dilihat dari filosofi budaya Gorontalo yang Islami berbunyi, "Adat bersendikan syarak; dan syarak bersendikan Kitabullah (Alquran)." Syarak adalah hukum yang berdasarkan syariat Islam. Karena itu, Gorontalo ditetapkan sebagai salah satu dari 19 daerah hukum adat di Indonesia. Raja pertama di Kerajaan Gorontalo yang memeluk agama Islam adalah Sultan Amai, yang kemudian namanya diabadikan sebagai nama pendidikan tinggi Islam di Gorontalo, STAIN Sultan Amai. Kota Gorontalo juga dikenal sebuah salah satu dari empat kota utama di Sulawesi, yaitu Makassar, Manado, Gorontalo, dan Pare pare.

Wilayah hukum Kotapraja Gorontalo dibagi 3 kecamatan berdasarkan UU No. 29/1959 tersebut dan melalui Keputusan Kepala Daerah Sulawesi Utara No. 102 tanggal 4 Maret 1960 ditetapkan 39 kampung yang masih termasuk dalam wilayah Kotapraja Gorontalo yang terbagi atas 3 kecamatan yaitu Kecamatan Kota Selatan, Kecamatan Kota Barat dan Kecamatan Kota Utara. Sejak tahun 2003 sudah dua kali terjadi pemekaran kecamatan di Kota Gorontalo sehingga bertambah menjadi 6 kecamatan yang sebelumnya hanya 3 kecamatan.

Terkait dengan jumlah lembaga pendidikan madrasah di kota ini adalah: Jumlah Madrasah Aliyah (MA) di Gorontalo sebanyak 42 Madrasah, Madrasah Tsanawiyah (MTsn) sebanyak 70 madrasah dan Madrasah Ibtidaiyah (MIS) sebanyak 97 madrasah. Raudhatul Athfal (RA) sebanyak 42 sekolah. Total madrasah yang terdapat di Provinsi Gorontalo sebanyak 251 madrasah. Guru Madrasah di Gorontalo yang telah mengikuti kegiatan pendidikan dan pelatihan berbagai jenis diklat pada jenjang madrasah mulai dari RA sebanyak 9 guru, MIS
57 guru, MTs 80 guru dan MA sebanyak 71 guru.

\section{Deskripsi variabel dan indikator}

Penelitian Pengaruh Diklat Terhadap Kinerja Guru Madrasah, memfokuskan tamatan pada guru-guru madrasah yang pernah diklat pada tahun 2016/2017 di BDK Manado termasuk Kabupaten/Kota gorontalo dan Kota Ternate. Berdasarkan desain operasional penelitian ini, sampel yang dipilih adalah 24 orang guru dan kepala madrasah.

Terdapat dua variabel yang dilihat dari penelitian ini yaitu variabel bebas dan variabel terikat. Variabel bebas adalah pendidikan dan pelatihan (Diklat), sedangkan variabel terikat adalah Kinerja Guru. Pada aspek Diklat, pernyataan atau indikator yang diamati adalah terkait metode diklat $\left(\mathrm{X}_{1}\right)$, materi diklat $\left(\mathrm{X}_{2}\right)$, dan pelatih/widyaiswara $\left(\mathrm{X}_{3}\right)$. Sedangkan pada aspek kinerja guru (Y), difokuskan pada kompetensi pedagogik, kompetensi kepribadian, kompetensi profesional, dan kompetensi sosial. Tentu mengacu pada Undang-Undang No. 14 Tahun 2005 tentang Guru dan Dosen. Secara rinci sub variabel penelitian yang mencakup aspek Diklat, meliputi 3 dimensi, dan 28 pernyataan, yaitu dimensi materi diklat, mencakup 7 pernyataan; dimensi pelatih/widyaiswara mencakup 7 pernyataan; dan dimensi metode diklat, mencakup 14 pernyataan.

Untuk aspek kinerja guru yang dicapai para guru madrasah dalam melaksanakan tugas yang dibebankan. Dimensi dan indikator penelitian yang sepenuhnya mengacu pada UU Nomor 14 Tahun 2005 tentang Guru dan Dosen yang mensyaratkan guru memiliki kompetensi: pedagogik, kepribadian, profesional, dan kompetensi sosial. Secara rinci sub variabel penelitian meliputi 14 dimensi dengan 61 pernyataan, yaitu dimensi mengenai karakter peserta didik mencakup 4 pernyataan; dimensi penguasaan teori belajar mencakup 6 pernyataan; dimensi pengembangan kurikulum mencakup 3 pernyataan; dimensi kegiatan pembelajaran mencakup 5 pernyataan; dimensi pemahaman dan pengembangan potensi guru mencakup 4 pernyataan; dimensi komunikasi dengan peserta didik mencakup 3 pernyataan; dimensi penilaian dan evaluasi mencakup 5 
pernyataan; dimensi bertindak sesuai norma agama, hukum, sosial, dan kebudayaan nasional mencakup 5 pernyataan; dimensi menunjukkan pribadi yang dewasa dan teladan mencakup 5 pernyataan; dimensi etos kerja, tanggung jawab, dan rasa bangga menjadi guru mencakup 8 pernyataan; dimensi bersikap inklusif, bertindak obyektif, serta tidak diskriminatif mencakup 3 pernyataan; dimensi komunikasi dengan sesama guru, tenaga pendidikan, orang tua peserta didik dan masyarakat mencakup 3 pernyataan; dimensi penguasaan materi, struktur konsep, dan pola pikir keilmuan yang mendukung mata pelajaran yang diampu mencakup 3 pernyataan; dan dimensi pengembangan profesi melalui tindakan reflektif mencakup 4 pernyataan.
Pengukuran variabel yang digunakan dalam penelitian ini adalah dengan menggunakan skala Likert, mengukur dengan cara menghadapkan seorang responden pada sebuah pernyataan dan kemudian diminta untuk memberikan jawaban yang diberi skor 1 sampai 5, yaitu Sangat Baik: skor 5; Baik: skor 4; Tidak Tahu: skor 3; Kurang Baik: skor 2, Sangat Tidak Baik: skor 1.

\section{Identifikasi Responden}

Responden penelitian di Gorontalo sebanyak 24 orang, terdiri atas guru dan kepala sekolah/wakasek/pengawas. Sampel guru yang pernah diklat pada BDK Manado (Kota Gorontalo Wilayah kerja BDK Manado) tahun 2016/2017.

Tabel 4. Distribusi aspek identitas responden

\begin{tabular}{cclccc}
\hline \multirow{2}{*}{ No. } & \multirow{2}{*}{ Tahun } & \multicolumn{1}{c}{ Jenis diklat yang diikuti } & \multicolumn{2}{c}{ Jumlah responden } \\
\cline { 3 - 5 } & & Guru & $\begin{array}{c}\text { Kepsek/ } \\
\text { Wakasek }\end{array}$ & \\
\hline 1 & 2017 & Diklat Guru Mata Pelajaran Ekonomi & 3 & 3 & 25 \\
\hline 2 & 2017 & Diklat Guru Mata Pelajaran Qur'an Hadits & 1 & 1 & 8,3 \\
\hline 3 & 2017 & Diklat Guru Mata Pelajaran Seni Budaya & 1 & 1 & 8.3 \\
\hline 4 & 2017 & Diklat Guru Mata Pelajaran Kimia & 2 & 2 & 16,6 \\
\hline 5 & 2017 & Diklat Guru Mata Pelajaran Fisika & 1 & 1 & 8,3 \\
\hline 6 & 2016 & Diklat Guru Mata Pelajaran Bahasa Indonesia & 1 & 1 & 8,3 \\
\hline 7 & 2017 & Diklat Guru Mata Pelajaran Sejarah Kebudayaan & 1 & 1 & 8,3 \\
\hline 8 & 2016 & Diklat Guru Mata Pelajaran Tematik & 1 & 1 & 8,3 \\
\hline 9 & 2017 & Diklat Guru Mata Pelajaran Antropologi & 1 & 1 & 8,3 \\
\hline \multicolumn{7}{c}{ Jumlah } & 12 & 12 & 100 \\
\hline
\end{tabular}

Sumber: Kuesioner (diolah)

\section{Analisis Proses Pelaksanaan Diklat}

Pengukuran variabel yang digunakan dalam mengukur proses pelaksanaan diklat di BDK Manado adalah dengan menggunakan skala Likert, mengukur dengan cara menghadapkan seorang responden pada sebuah pernyataan dan kemudian diminta untuk memberikan jawaban yang diberi skor 1 sampai 5, yaitu Sangat Baik: skor 5; Baik: skor 4; Tidak Tahu: skor 3; Kurang Baik: skor 2, Sangat Tidak Baik: skor 1 .

Terdapat 3 dimensi, yang menjadi tolak ukur proses pelaksanaan diklat, yaitu materi diklat, widyaiswara, dan metode diklat. Responden yang memberikan penilaian adalah para guru yang pernah diklat. Para responden cukup antusias mengisi angket yang telah diedarkan, bahkan sebagian menganggap dengan mengisi angket ini, harapannya mereka kembali dipanggil untuk mengikuti diklat. Saking gembiranya, mereka ingin diklat berkali-kali. Tapi apalah daya, pihak diklat hanya membolehkan ASN diklat sekali dalam rentang waktu 3 tahun. Diutamakan guru yang belum pernah diklat. Berikut ini, hasil analisis proses pelaksanaan diklat di BDK Manado.

\section{Dimensi Materi Diklat}

Tingkat keterlibatan responden guru dalam memberikan penilaian terhadap dimensi materi diklat di Gorontalo diamati melalui tujuh indikator. Pada indikator ini, Responden menganggap bahwa materi diklat yang disampaikan terkategori baik yakni 4,4. Materi 
yang disiapkan pihak diklat mengacu pada analisis kebutuhan peserta diklat. contoh materi diklat mata pelajaran Ekonomi yang telah diikuti oleh Deliana Mustafa, S.Pd., Guru mata pelajaran Ekonomi MA dengan susunan kelompok mata diklat: Kelompok Dasar; Peningkatan Kualitas Kemenag mengenai Guru Madrasah, Peningkatan Kualitas Pembangunan Bidang Agama, Pengembangan SDM Aparatur Kementerian Agama, Peningkatan Kualitas Diklat Teknis Pendidikan dan Keagamaan. Kelompok Inti; Pengembangan Materi Esensial Mata Pelajaran Ekonomi, Pengembangan Model-Model Pembelajaran, Pengembangan Penilaian Pembelajaran, Analisis Permasalahan Pembelajaran, Pengembangan Media Pembelajaran, Analisis dan Pengembangan Perencanaan Pembelajaran, Publikasi Ilmiah dan Karya Inovatif. Kelompok Penunjang; Pre Test, Post Test, Building Learning Commitment. Hal tersebut apabila dilihat dari surat tanda tamat pendidikan dan pelatihan. Namun dalam pelaksanaan diklat dianggap masih kurang memadai menurut pernyataan beberapa guru terkait Widyaiswara/instruktur dalam membawakan materi belum sistematis dan kurang praktis, serta kesiapan/ketersediaan bahan ajar bagi peserta diklat dianggap masih kurang memadai. Begitupun, dengan materimateri diklat, dianggap masih kurang menyentuh secara substantif dengan kebutuhan dalam pembelajaran di dalam kelas (Wawancara Deliana, Gorontalo tanggal 5 Agustus 2018). Materi yang disampaikan hanya bersifat umum saja, seperti yang diungkapkan oleh Bapak Umar Abbas yang pernah mengikuti diklat substantif Bahasa Arab di Ternate menyatakan bahwa materinya seharusnya sistematis, dan penambahan jam diklat terhadap materi inti (Wawancara, tanggal 26 Juli 2018).

\section{Dimensi Widyaiswara}

Berhasil tidaknya proses diklat itu, banyak dipengaruhi oleh WI/instrukturnya. Para WI yang ada di BDK Manado, hampir semuanya telah memenuhi standar yang telah ditentukan. Bahkan sudah ditetapkan spesialisasi dari masing-masing WI oleh Kepala Badan Litbang dan Diklat Kemenag RI. Terkait dengan dimensi WI, mayoritas responden Gorontalo menanggapinya dengan kategori sangat baik dan baik yakni 4,6. Namun demikian masih terdapat guru mata pelajaran yang menganggap bahwa: masih terdapat Widyaiswara belum menguasai materi pelatihan; belum memiliki pengalaman berkenaan dengan pembelajaran; tidak menguasai materi pelatihan; kurang memberi contoh-contoh terkait materi; dan tidak memberikan pengarahan yang mudah dicerna sebelum berdiskusi. Hal tersebut diungkapkan oleh responden. Sementara responden yang menyatakan bahwa WI belum menerapkan metode pelatihan dengan baik, sehingga peserta diklat tidak memahami materi yang disampaikan. Salah satunya diungkapkan oleh Maria Yuliana, dominan WI menguasai materi pembelajaran, namun masih terdapat WI yang kurang menguasai materi diklat, terbukti tidak memberikan contoh yang konkret dalam pelatihan diklat. (Wawancara, Gorontalo 3 Agustus 2018).

Widyaiswara mengetahui tujuan diklat mata pelajaran yakni menyediakan wahana untuk pengembangan ide, kreativitas serta motivasi Guru mata pelajaran dalam melaksanakan berbagai pengembangan profesi yang berkualitas sesuai dengan ketentuan yang telah ditentukan. Meningkatkan Guru mata pelajaran secara menyeluruh, terstruktur, dan sistematik sesuai dengan standar kompetensi Guru. Membantu Guru mata pelajaran dalam merealisasikan penyusunan berbagai jenis pengembangan profesi, agar secara kualitatif hasilnya memberikan kontribusi positif, baik untuk keperluan peningkatan karier kepangkatan Guru maupun untuk peningkatan profesionalnya. Mengembangkan komunikasi dan saling tukas informasi maupun kemampuan antar sesama guru agar menambah wawasan yang dapat meningkatkan mutu profesionalnya Guru. Mempersiapkan guru yang unggul dan mumpuni untuk mengikuti berbagai kegiatan kompetensi yang di selenggarakan di pusat maupun di daerah.

Tindak lanjut diklat mata pelajaran pembinaan kompetensi lanjutan yang di laksanakan oleh BDK Manado terbentuknya kelompok-kelompok pengembangan profesi di masing-masing daerah, baik secara mandiri maupun terintegrasi dengan organisasi profesi yang sudah ada, dampak dari kegiatan ini 
terhadap peningkatan kompetensi peserta selaku pendidik antara lain secara umum diklat ini berdampak pada meningkatnya pemahaman peserta khususnya kompetensi pedagogik dan kompetensi profesional. Secara khusus Widyaiswara mengetahui bahwa diklat mata pelajaran berpengaruh pada meningkatnya pemahaman pendidik bisa membagikan pemahaman yang di dapatkan pada diklat khususnya dalam hal penilaian kinerja berkelanjutan yang meliputi pengembangan diri, publikasi ilmiah dan karya inovatif kepada pendidik di lingkungan sekolahnya. Masih terdapat Widyaiswara hanya sebatas mengetahui Tujuan dan tindak lanjut pelaksanaan diklat belum di implementasikan secara menyeluruh mengenai hal tersebut. (Wawancara Deliana, Gorontalo tanggal 5 Agustus 2018).

\section{Dimensi Metode Diklat}

Dalam penyajian materi diklat, pihak WI/instruktur menggunakan metode yang cukup beragam sesuai dengan kondisi dan kebutuhan diklatnya. Pada umumnya menggunakan metode ceramah, tanya jawab, diskusi, simulasi, dan sebagainya. Terkait dengan metode diklat di Gorontalo, hasilnya menunjukkan nilai yang baik yakni 4,5. Idealnya metode yang diterapkan dalam kegiatan diklat sangat beragam dan runtut sesuai dengan tujuan pelaksanaan diklat dan juga metodenya mutakhir menyesuaikan kurikulum K13 yang dijalankan oleh madrasah. Metode Pembelajaran sebagai cara yang digunakan untuk mengimplementasikan rencana yang sudah disusun dalam bentuk kegiatan nyata dan praktis untuk mencapai tujuan pembelajaran. Di antara metode yang sering di gunakan Widyaiswara pada diklat guru mata pelajaran di antaranya sebagai berikut.

Metode ceramah sudah sejak lama ceramah digunakan oleh para widyaiswara dengan alasan keterbatasan waktu dan buku teks. Hal ini menunjukkan adanya kecenderungan menganggap metode ceramah sebagai metode belajar-mengajar yang mudah digunakan. Kecenderungan ini bertentangan dengan kenyataan bahwa tidak setiap widyaiswara dapat menggunakan metode ceramah dengan benar. Metode ceramah bergantung kepada kualitas personalitis widyaiswara, yakni suara, gaya bahasa, sikap, prosedur, kelancaran, kemudahan bahasa, dan keteraturan widyaiswara dalam memberi penjelasan: yang tidak dapat dimiliki secara mudah oleh setiap widyaiswara, dominan Widyaiswara masih menerapkan metode ceramah (Wawancara Sitti Nur Afni Oktavia Pasisingi, S.Pd.I, M.S.I. Guru mata pelajaran Sejarah Kebudayaan Indonesia pada MAS Darul Mubin, Gorontalo 4 Agustus 2018).

Metode diskusi yang digunakan widyaswara, dominan menerapkan metode ceramah namun masih terdapat yang menerapkan metode diskusi pada suatu kegiatan kelompok untuk memecahkan suatu masalah, dengan maksud untuk mendapat pengertian bersama yang lebih jelas dan lebih teliti mengenai materi atau untuk merampungkan keputusan bersama. dalam diskusi setiap peserta diklat diharapkan memberikan sumbangan sehingga seluruh kelompok kembali dengan pemahaman yang sama dalam suatu keputusan atau kesimpulan.

Tujuan widyaiswara menggunakan metode diskusi untuk pengembangan pikiran kritis, sikap demokratis, tujuan-tujuan kognitif tingkat tinggi, dan pengembangan sosialemosional. Secara terperinci tujuan pemakaian metode diskusi, yaitu Mengembangkan keterampilan bertanya, berkomunikasi, menafsirkan, dan menyimpulkan pada diri peserta diklat, Mengembangkan sikap positif terhadap sekolah, para widyaiswara, dan bidang studi yang dipelajari, Mengembangkan kemampuan memecahkan masalah dan konsep diri yang lebih positif. Meningkatkan keberhasilan peserta diklat dalam menemukan pendapat, Mengembangkan sikap terhadap isuisu kontroversial.

Penerapan metode diskusi tidak hanya sekedar untuk menyampaikan informasi kepada para peserta diklat. Hal yang penting dari penyampaian informasi adalah terbentuknya kondisi yang menguntungkan bagi peserta diklat untuk mengelola perolehan belajarnya. Kelebihan Metode Diskusi dapat merangsang peserta diklat untuk lebih kreatif khususnya dalam memberikan gagasan dan ide-ide, Dapat melatih untuk membiasakan diri bertukar pikiran dalam mengatasi setiap permasalahan, Dapat melatih peserta diklat untuk dapat 
mengemukakan pendapat atau gagasan secara verbal. Di samping itu, diskusi juga melatih peserta diklat untuk menghargai pendapat orang lain (Wawancara Nurlaila Djafar, S.Pd. Guru mata pelajaran Kimia MAN, Gorontalo 5 Agustus 2018).

Metode Kerja Kelompok digunakan widyaiswara dalam proses belajar-mengajar dengan tujuan memupuk kemauan dan kemampuan kerja sama di antara para peserta diklat, Meningkatkan keterlibatan sosioemosional dan intelektual para peserta diklat dalam proses belajar-mengajar yang diselenggarakan, dan Meningkatkan perhatian terhadap proses dan hasil dari proses belajarmengajar secara berimbang.

Kelebihan dan Kekurangan Metode Kelompok. Segi Kelebihan. Ditinjau dari segi pendidikan, kegiatan kelompok peserta diklat akan meningkatkan kualitas kepribadian, seperti: kerja sama, toleransi, kritis, disiplin dan sebagainya, Ditinjau dari segi ilmu jiwa akan timbul persaingan yang positif, karena anakanak lebih giat bekerja dalam kelompok masing-masing, Ditinjau dari segi didaktik, bahwa anak-anak yang pandai dalam kelompoknya dapat membantu temantemannya yang kurang pandai, terutama dalam rangka memenangkan "Kompetisi" antara kelompok. Segi negatif, metode kelompok memerlukan persiapan-persiapan yang agak rumit apabila dibandingkan dengan metode yang lain; misalnya metode ceramah, Apabila terjadi persaingan yang negatif, hasil pekerjaan akan lebih memburuk, Bagi anak-anak yang malas ada kesempatan untuk tetap pasif dalam kelompok itu dan kemungkinan besar akan mempengaruhi kelompok itu, sehingga usaha kelompok itu akan gagal (Wawancara Siti Nurain Arifin, S.Pd., guru mata pelajaran Fisika MA, Gorontalo 6 Agustus 2018).

Metode campuran dalam praktiknya metode campuran ini dapat diterapkan seorang widyaiswara dalam suatu situasi pengajaran di depan kelas, dengan persiapan yang baik dan sungguh-sungguh. Hal ini dikarenakan, kemampuan widyaiswara dalam menguasai bahan itu sendiri melakukan latihan-latihan praktik terus dan mampu menguasai berbagai metode. widyaiswara menguasai berbagai macam metode-metode dan menerapkan secara bervariasi di kelas secara bersungguh sungguh (Wawancara Suciati, S.Pd.I, Guru mata pelajaran Alquran-Hadist Madrasah Tsanawiyah Swasta Darul Mubin, Gorontalo 7 Agustus 2018).

\section{Analisis Kinerja Guru}

Berdasarkan uraian tentang guru madrasah yang telah mengikuti diklat dan pelatihan di Balai Diklat Manado sebagaimana dapat dilihat pada tabel 1, tabel 2, dan tabel 3, pelaksanaan kediklatan belum merata. Dengan demikian, maka akan memengaruhi kinerja mereka dalam melaksanakan pembelajaran di kelas. Rentang waktu yang cukup lama bagi guru madrasah antara yang mengikuti diklat pada tahun 2009 sampai 2018, tentu akan berpengaruh dan berbeda bagi guru madrasah yang mengikuti diklat pada tahun 2018. Para guru yang mengikuti diklat pada tahun 2018 tentu memiliki kompetensi sebagaimana amanah yang dijabarkan pada undang-undang guru dan dosen.

Variabel kinerja merupakan hasil kerja yang dicapai oleh para guru madrasah setelah mengikuti Diklat di Manado. Dimensi dan indikator penelitian sepenuhnya mengacu pada Undang Undang Nomor 14 Tahun 2005 Tentang Guru dan Dosen. Di sana, mensyaratkan guru memiliki kompetensi, meliputi: kompetensi pedagogik, kompetensi kepribadian, kompetensi profesional, dan kompetensi sosial.

Dalam penelitian ini kinerja guru dijabarkan dalam 14 dimensi dengan 61 indikator. Responden yang memberikan penilaian terhadap kinerja guru setelah diklat adalah kepala madrasah/wakil kepala dan pengawas. Dengan adanya diklat ini sangat membantu guru di kelas, terutama banyak informasi-informasi baru, pengetahuan yang baru dan sangat bermanfaat untuk diajarkan kepada anak didiknya demi kemajuan pendidikan di tanah air. Hampir semua indikator terkait kinerja guru mendapat respons baik dan sangat baik. Hal ini mengindikasikan betapa besar manfaat dan kegunaan diklat bagi guru madrasah yang dilaksanakan oleh BDK Manado. Artinya, pengaruh diklat berkorelasi positif terhadap kinerja menyatakan bahwa ilmu yang didapatkan dari pendidikan dan pelatihan 
sangat bermanfaat bagi perkembangan dirinya (guru), perkembangan sekolah serta perkembangan siswa. Pendidikan dan pelatihan yang diikuti guru sangat mempengaruhi kinerja guru sehingga setelah mengikuti pendidikan dan pelatihan terjadi peningkatan kinerja misalnya guru akan lebih bersemangat lagi dalam menjalankan tugas pekerjaannya.

Karakter peserta didik di Gorontalo menunjukkan kategori sangat baik $(4,7)$. Pada saat guru mata pelajaran di Madrasah merancang dan merencanakan pembelajaran seorang guru perlu memperhatikan kemampuan dan karakteristik individual peserta didiknya, kemudian merancang perlakuan yang kan diberikan dari adanya perbedaan kemampuan dan karakteristik itu. Guru mata pelajaran biasanya menentukan pengelolaan kelas, merancang penggunaan metode pembelajaran, pemberian tugas latihan. Salah satu contoh, peserta didik yang terkategori pintar guru cukup memberikan penjelasan bahan materi ajar melalui metode ceramah, di sisi lain pada peserta didik yang terkategori sedang atau kurang pintar, yang di terapkan guru berupa penjelasan dengan menggunakan media/alat peraga yang dibutuhkan, pemberian tugas latihan menyelesaikan soal, memberikan tugas membaca dan mempelajari materi dari buku pelajaran yang tersedia di perpustakaan sekolah, menambah jam belajar dan peserta didik yang terkategori kurang pintar guru mata pelajaran biasanya menambahkan dengan memberikan tugas pekerjaan rumah. Guru mengenal karakter peserta didik, merupakan sikap yang telah dimiliki dan dilakukan pendidik, dengan demikian pendidik mengetahui aspirasi atau tuntutan peserta didik yang dijadikan bahan pertimbangan dalam penyusunan program bagi peserta didik, sehingga kegiatan pembelajaran memenuhi kebutuhan, minat mereka dan tepat berdasarkan dengan perkembangan mereka. perlunya" memahami peserta didik pertimbangan psikologis, kegiatan akan menarik dan berhasil apabila sesuai dengan minat, bakat, kemampuan, keinginan, dan tuntutan peserta didik. pertimbangan sosiologi, bahwa secara naluri siswa merasa ikut serta memiliki dan aktif mengikuti kegiatan yang ada. Beberapa contoh kegiatan ekstrakurikuler dengan mengarahkan bakat minat siswa sesuai yang diminati, yaitu olah raga volley, sepak bola, pramuka, palang merah remaja, bimbingan bahasa Inggeris di luar jam pembelajaran (Wawancara, Gorontalo, 30 Juli 2018, Anis Domili, S.Ag, Kepala Madrasah Tsanawiah Al-Huda Kota Gorontalo).

Berkaitan dengan penguasaan teori belajar, terdapat 6 indikator yang menjadi kinerja guru dalam pelaksanaan pembelajaran di kelas. Mayoritas responden di Gorontalo memberikan penilaian terkategori baik, yaitu nilai rata-rata 4,5. Penguasaan teori belajar merupakan kompetensi profesional yang di miliki seorang Guru Madrasah terkait dengan mata pelajaran yang di ampunya, dimensi penguasaan teori belajar di lakukan karena guru mata pelajaran di MA Gorontalo berupaya meningkatkan wawasan melalui diklat guru mata pelajaran, karena guru yang tidak menguasai teori belajar kurang memperlihatkan kemampuan penguasaan materi belajar terjebak ke dalam pola dan materi yang menjenuhkan, membosankan dan pada akhirnya peserta didik kurang membangkitkan gairah belajarnya. Penguasaan teori belajar yang di ampu oleh guru mata pelajaran di madrasah tidak hanya mencakup materi semata tapi semua yang berhubungan pelaksanaan pembelajaran metode dan teknologi pembelajaran. Penyiapan materi bahan ajar masih ada guru yang mengambil jalan pintas dengan meng-copy paste milik rekan sejawat dari bidang studi yang sama ataupun yang diperoleh dari KKG/ MGMP. Kemandirian dan kreativitas guru belum tampak dalam penguasaan bahan ajar. tidak konsisten antara perencanaan dan persiapan dengan pelaksanaan pembelajaranpun sering terjadi, karena apa yang di salin sekedar di tunjukkan untuk memenuhi persyaratan administrasi di sekolah ataupun memperoleh angka kredit semata (Wawancara, Gorontalo 27 Juli, Suharmin H. Alinti,S. Ag, Kepala Madrasah Aliyah Swasta Al-Huda Gorontalo, Kota Gorontalo).

Dimensi pengembangan kurikulum setiap guru menurut responden setiap madrasah di Gorontalo direspons dengan kategori sangat baik $(4,6)$. Pengembangan dan penyusunan kurikulum yang baik yang baik akan diperoleh apabila guru memiliki pengetahuan dan penguasaan materi yang baik pula. diklat yang memadai di perlukan agar guru dapat 
mewujudkan kemampuan dan keterampilan dalam mengembangkan kurikulum merancang, mengembangkan dan merancang, menyusun kurikulum merupakan salah satu bahan ajar yang diberikan. Merancang dan menyiapkan bahan ajar, menyampaikan bahan ajar dan melaksanakan pembelajaran guru mata pelajaran di madrasah hendaknya merancang pula pengelolaan kelas sesuai dengan materi, tujuan, dan kebutuhan yang dihadapi.

Untuk dimensi kegiatan pembelajaran, di Gorontalo nilainya 4,6, namun yang masih perlu dikembangkan oleh guru, adalah proses pembelajaran terpadu. Kegiatan pembelajaran akan dapat berhasil dengan baik apabila guru sejak awal dapat mengondisikan kegiatan belajar secara efektif. Upaya yang perlu dilakukan untuk mewujudkan kondisi awal pembelajaran yang efektif yaitu terkait dengan visi kurikulum dan mengaitkannya dengan konteks kehidupan peserta didik sehari-hari. Ini masih dianggap kurang oleh sebagian responden. Begitupun dengan cara guru mengelola kelas dengan efektif, sehingga terkesan sibuk dengan kesibukannya sendiri, mengurus administrasi sertifikasinya, dan lain sebagainya. Seperti dikemukakan oleh salah seorang responden Suparno, bahwa guru-guru kita di sekolah sibuk dengan kesibukan pribadinya, minta izin sejam, kadang tidak tepat waktu (Wawancara, Gorontalo, tanggal 26 Juli 2018).

Selanjutnya untuk dimensi pemahaman dan pengembangan potensi, responden di Gorontalo menilai dengan kategori baik yakni 4,5. Pengembangan potensi rohaniah Guru menanamkan nilai-nilai keagamaan dengan menciptakan sikap toleransi antar umat beragama, budaya dengan memahami kehidupan yang beragam di sekolah peserta didik berinteraksi dengan lingkungannya memahami adanya perbedaan.

Dimensi komunikasi dengan peserta didik, tetap terus menjadi perhatian oleh seorang guru, dan hasilnya di setiap guru madrasah dinilai oleh responden Gorontalo dengan kategori sangat baik yakni 4,8. Dari dimensi penilaian dan evaluasi, setiap guru madrasah telah melakukan penilaian dan evaluasi terkait dimensi ini. Hasilnya di
Gorontalo direspons dengan kategori sangat baik yakni rata-rata 4,6.

Dimensi bertindak sesuai nama agama, hokum, social, dan kebudayaan nasional ini mendapat penilaian dari responden Gorontalo dengan kategori sangat baik (nilai rata-rata 4.7). Dimensi menunjukkan pribadi yang dewasa dan teladan, setiap guru sudah pasti harus menjadi teladan bagi anak didiknya, karena memang jiwa peserta didik masih terus mencari jati dirinya, terutama ingin mencontoh orang-orang yang sukses. Untuk dimensi ini direspons Gorontalo dengan kategori sangat baik yakni rata-rata 4,6

Meskipun tampak pada nilai yang baik (4.5) di aspek dimensi etos kerja, tanggung jawab, dan rasa bangga menjadi guru, akan tetapi pada indikator tanggung jawab seorang guru dalam memenuhi jam mengajarnya dan kegiatan guru di luar jam pelajaran berdasarkan izin dari kepala sekolah, dianggap oleh beberapa kepala sekolah kurang setuju dengan hal tersebut. Pada dimensi ini, dari 8 indikator yang menjadi variabel penilaian.

Untuk dimensi bersikap inklusif, bertindak obyektif, serta tidak diskriminatif, dari 3 indikator yang menjadi variabel penilaian responden direspons dengan kategori baik yakni rata-rata 4,4. Tiga indikator dalam dimensi komunikasi dengan sesame guru, tenaga pendidik, orangtua peserta didik dan masyarakat, hasilnya direspons dengan kategori baik dengan nilai rata-rata 4,3 oleh responden. Terkait dimensi penguasaan materi, struktur konsep, dan pola piker keilmuan yang mendukung mata pelajaran yang diampu, guru madrasah telah dianggap mahir oleh setiap responden, sehingga hasil yang diberikan responden Gorontalo dinilai dengan kategori baik dengan nilai rata-rata 4,4 .

Terkait dimensi pengembangan keprofesian melalui tindakan reflektif, 4 indikator yang menjadi variabel penilaian menunjukkan nilai kategori yang baik dengan nilai rata-rata 4.5). Namun demikian pernyataan terkait pemanfaatan TIK dalam berkomunikasi, masih kurang. Banyak faktor yang menjadi kendalanya seperti jaringan, kesiapan guru menerima era teknologi digital masih dianggap kurang. Seperti diungkapkan oleh Sutisna Abdullatif, bahwa kelemahan pada guru-guru 
kita ini adalah terkait TIK ini, banyak guru kita yang belum menguasai terkait teknologi dengan baik, mereka masih menggunakan cara biasa yang sudah ketinggalan (Wawancara, tanggal 2 Agustus 2018).

Pelaksanaan diklat cukup menampung peserta dari berbagai daerah (Wawancara, Deliana Mustafa, S.Pd., Guru mata pelajaran Ekonomi MAN 1 Kota Gorontalo, 27 Juli 2018). Seluruh peserta diklat yang telah mengikuti diklat mata pelajaran memperoleh sertifikat dengan angka kredit sesuai dengan perhitungan jumlah jam pembelajaran diklat yang telah di ikuti. Perhitungan tersebut di mulai dari 30-80 jam belajar dihitung satu angka kredit, 80-100 jam dihitung sebanyak 2 angka kredit dengan volume waktu minimal 6 hari dan maksimal 10 hari. Jam belajar dimulai dari jam 07.30 sampai dengan jam 17.30. Selanjutnya Pasca kegiatan diklat, guru harus membuat resume atau laporan yang diserahkan kepada Kepala Seksi Guru dan Ketenagakerjaan yang memanfaatkan untuk bahan acara workshop. Dan apabila ada pertemuan di kabupaten atau kota, guru yang telah mengikuti diklat mengimplementasikan materi diklat pada satuan kerja masing-masing melalui MGMP dengan melakukan presentasi di hadapan para guru dan Kantor Kemenag Kabupaten atau Kota (Wawancara, Gorontalo, 26 Juli 2018 Silfi, Seksi Guru dan Tenaga Kependidikan Kanwil Kemenag Provinsi Gorontalo).

Pelaksaan diklat Kuota pesertanya terbatas \pm 30 orang mata diklat untuk seIndonesia Timur sehingga tidak dapat mengakomodir permintaan seluruh guru di wilayah kerja masing-masing. Keikutsertaan guru pada diklat lebih banyak diikutkan diklat yang masih bersifat lokal (Wawancara, Gorontalo 25 Juli 2018 Nancy Zakaria, M.Hi. Kepala Seksi Guru dan Tenaga Kependidikan Kanwil Kemenag Gorontalo). Jumlah kegiatan diklat yang dilaksanakan tiap tahun belum dapat mengakomodir jumlah guru untuk pengembangan diri mereka, begitu pula pengawas belum semuanya mengikuti diklat. Terdapat beberapa guru yang tidak dapat naik pangkat karena masih kurangnya diklat pengembangan diri. Salah satu syarat untuk kenaikan pangkat dari golongan III/a ke III/b harus mengikuti 3 (tiga) diklat pengembangan diri, dari golongan III/c ke golongan III/d, golongan III/d ke golongan IV/a dan golongan IV/a ke golongan IV/b minimal 4 (empat) diklat pengembangan diri yang disesuaikan dengan mata pelajaran masing-masing guru. Kemudian dari golongan IV/b ke golongan IV/c harus mengikuti dan lulus 5 (lima) diklat materi pengembangan diri (Wawancara Kepala Seksi Kepegawaian Kemenag Kota Gorontalo, 26 Juli 2018).

\section{SIMPULAN}

Pelaksanaan pendidikan dan pelatihan terhadap guru madrasah di Kota Gorontalo, memiliki pengaruh terhadap kinerja guru. Pengaruh tersebut adalah guru memiliki peningkatan dalam kompetensi pedagogik, kompetensi kepribadian, kompetensi profesional, dan kompetensi sosial setelah mengikuti kediklatan. Pengaruh pendidikan dan pelatihan guru mata pelajaran terhadap peningkatan kinerja guru di Kota Gorontalo rata-rata masuk kategori baik. Hal ini didukung dengan hasil survei dan wawancara terhadap beberapa guru dan materi yang disiapkan pihak pelaksana diklat mengacu pada analisis kebutuhan peserta diklat. Widyaiswara cukup memahami dan menguasai tujuan dan prosedur penyelenggaraan diklat sehingga kualifikasi akademik widyaiswara sesuai dengan tugas pokoknya dengan melibatkan instruktur yang kompeten dan profesional dan menerapkan metode yang variatif di antaranya metode ceramah, metode diskusi, metode kelompok, metode campuran dan penerapan disesuaikan dengan tujuan pelaksanaan diklat. Namun demikian masih terdapat widyaiswara yang belum menguasai materi diklat dan hanya menerapkan satu metode yaitu metode ceramah.

Faktor pendukung pelaksanaan diklat terhadap guru madrasah, bahwasanya fasilitas pelaksanaan diklat dapat menampung peserta dari berbagai daerah. Seluruh peserta diklat yang telah mengikuti diklat mata pelajaran memperoleh sertifikat dengan angka kredit sesuai dengan perhitungan jumlah jam pembelajaran diklat yang telah di ikuti namun Kuota peserta diklat terbatas hanya 30 orang per mata pelajaran diklat untuk se-Indonesia Timur sehingga pengusulan kenaikan pangkat mengalami keterlambatan karena tidak dapat 
mengakomodir permintaan seluruh guru di wilayah kerja masing-masing.

\section{SARAN}

Balai Diklat Keagamaan Manado hendaknya menambah kuota peserta diklat agar sebagian besar guru mata pelajaran dapat terakomodir di wilayahnya masing-masing dan rekruitmen widyaiswara selayaknya berasal dari latar belakang pendidikan sesuai kompetensi profesional. Selain itu, ditekankan semua widyaiswara menguasai metode pembelajaran yang variatif tidak terbatas pada metode ceramah saja yang dominan. Akan tetapi lebih variatif dan inovatif dalam memberikan materi diklat.

\section{DAFTAR PUSTAKA}

Athiyah, C. U. (2019) 'Evaluasi Program Unggulan Pusdiklat Tenaga Teknis Pendidikan dan Keagamaan 2018', EDUKASI: Jurnal Penelitian Pendidikan Agama dan Keagamaan, 17(1). doi: 10.32729/edukasi.v17i1.585.

Cowling, Alan \& James, P. (1996) The Essence of Personnel Management an Industrial Relation. Yogyakarta: Andi.

Djailani, D. (2012) 'Peningkatan Kompetensi Guru MTsN Kota Banda Aceh Melalui Supervisi Pengajaran', Jurnal Ilmiah Didaktika, 12(2). doi: 10.22373/jid.v12i2.456.

Faizah, Z., Hanief, M. and Dina, L. N. A. B. (2019) 'Profesionalisme Guru Dalam Meningkatkan Mutu Pendidikan di Madarsah Ibtidaiyah Tahfidz Al-Asyhar Malang', JPMI: Jurnal Pendidikan Madrasah Ibtidaiyah, 1(3). Available at:

http://riset.unisma.ac.id/index.php/JPM I/article/view/3234.

Furqon (2009) Statistik Terapan untuk Penelitian,. Bandung: Alfabeta.

Hanun, M.Pd, F. (2018) 'Evaluasi Penyelenggaraan Diklat di Kementerian Agama', EDUKASI: Jurnal Penelitian Pendidikan Agama dan Keagamaan, 16(2). doi: 10.32729/edukasi.v16i2.477.

Hidayati, U. (2018) 'Respon Madrasah
Terhadap Pelaksanaan Sekolah Lima Hari dan Pengembangan Karakter', EDUKASI: Jurnal Penelitian Pendidikan Agama dan Keagamaan, 16(3). doi: 10.32729/edukasi.v16i3.478.

Miyono, N. and Rosidin, R. (2017) 'Determinan Budaya Kerja Guru Madrasah Tsanawiyah di Kabupaten Demak', EDUKASI: Jurnal Penelitian Pendidikan Agama dan Keagamaan, 15(3). doi: 10.32729/edukasi.v15i3.312.

Morissan (2014) Metode Penelitian Survey. Jakarta: Kencana Prenadamedia Group.

Nuranti, N., Hanief, M. and Mustafida, F. (2019) 'Strategi Guru dalam Membentuk Karakter Siswa di Madrasah Ibtidaiyah Bustanul Ulum Kota Batu', JPMI: Jurnal Pendidikan Madrasah Ibtidaiyah, 1(3). Available at: http://riset.unisma.ac.id/index.php/ JPMI/article/view/3164.

Nurhilaliati, N. (2019) 'Kualitas Kepemimpinan Kepala Madrasah Perempuan di Lingkungan Pondok Pesantren', EDUKASI: Jurnal Penelitian Pendidikan Agama dan Keagamaan, 17(1). doi: 10.32729/edukasi.v17i1.541.

Puspayanti, A. (2016) 'Studi Evaluatif Penyelenggaraan Diklat Teknis pada Balai Diklat Keagamaan Denpasar Tahun 2015', Profesi, 1(11).

Sadirman, A. . (2004) Interaksi dan Motivasi Belajar Mengajar. Jakarta: Rajawali Pers.

Saud, U. S. (2008) Pengembangan Profesi Guru. Bandung: Alfabeta.

Sevilla, C. (1993) An Introduction to Research Methods, diterj. Alimuddin Tuwu: Pengantar Metode Penelitian. Jakarta: UI-Press.

Sopandi, E. (2019) 'Evaluation of Leading Education Program on Madrasah Aliyah Negeri Insan Cendekia Serpong Tangerang Selatan', EDUKASI: Jurnal Penelitian Pendidikan Agama dan Keagamaan, 17(2). doi: 10.32729/edukasi.v17i2.612. 
Sudjana, N. (1989) Nana Dasar-Dasar Proses

Belajar-Mengajar. Bandung: Sinar Baru.

Sumarni, S. (2017) 'Evaluasi Implementasi Kurikulum 2013 di Madrasah', EDUKASI: Jurnal Penelitian Pendidikan Agama dan Keagamaan, 15(3). doi: 10.32729/edukasi.v15i3.453.

Suparlan (2011) Tanya Jawab Pengembangan Kurikulum dan Materi Pembelajaran: Curriculum and Learning Material Development. Jakarta: Bumi Aksara.

Undang-Undang Republik Indonesia. 2003. Undang-Undang RI Nomor 20 Tahun 2013 tentang Sistem Pendidikan Nasional. Jakarta: Sekretaris Negara Republik Indonesia.
Undang-Undang Republik Indonesia. 2005. Undang-Undang Republik Indonesia Nomor 14 Tahun 2005 tentang Guru dan Dosen. Jakarta: Menteri Hukum Dan Hak Asasi Manusia Republik Indonesia

Wibowo, A. (2013) 'The Religion Teachers Performance at Aliya Madrasa after their Completing Training Program in Province of West Nusa Tenggara', Analisa, 20(2), p. 245. doi: 10.18784/analisa.v20i2.180.

Wibowo, C. H. (2015) Problematika Profesi Guru Dan Solusinya Bagi Peningkatan Kualitas Pendidikan Di MTs. Negeri Nguntoronadi Kabupaten Wonogiri. IAIN Surakarta. Available at: http://eprints.iainsurakarta.ac.id/id/eprint/17. 